3. 2014 ESC Guidelines on the diagnosis and treatment of aortic diseases | European Heart Journal | Oxford Academic. Accessed July 9, 2021. https://academic.oup.com/eurheartj/article/35/41/ 2873/407693?login=true

4. Jonker FHW, Trimarchi $S$, Verhagen HJM, Moll FL, Sumpio BE, Muhs BE. Meta-analysis of open versus endovascular repair for ruptured descending thoracic aortic aneurysm. J Vasc Surg. 2010;51(4):1026-1032, doi:10.1016/j.jvs.2009.10.103

5. Hammo $S$, Larzon $T$, Hultgren $R$, et al. Outcome After Endovascular Repair of Ruptured Descending Thoracic Aortic Aneurysm: A National Multicentre Study. Eur J Vasc Endovasc Surg. 2019; 57(6): 788-794. doi:10.1016/j.ejvs.2018.10.029
6. Etienne $H$, Majewski $M$, Cochennec $F$, Segaux L, Becquemin J-P. Emergency Endovascular Interventions for Ruptured Descending Thoracic Aortic Aneurysm. Ann Vasc Surg. 2017;39:160166. doi:10.1016/j.avsg.2016.06.041

7. Tien TQ, Kien PD. Kết quả can thiệp nội mạch cấp cứu điều trị vỡ phình đông mach chủ ngực đoạn xuống. Tạp Chí Phẫu Thuật Tim Mạch Và Lồng Ngực Viêtt Nam. 2021;31:12-20. doi:10.47972/vjcts.v331i.497

8. Jonker FHW, Verhagen HJM, Lin PH, et al. Outcomes of endovascular repair of ruptured descending thoracic aortic aneurysms. Circulation. 2010;121(25):2718-2723.

doi:10.1161/CIRCULATIONAHA.109.908871

\title{
GIÁ TRI XÉT NGHIÊM FRUCTOSAMIN HUYẾT THANH TRONG PHẢN ÁNH ĐƯỜNG HUYẾT LÚC ĐÓI Ở BÊ̂NH NHÂN ĐÁI THÁO ĐƯỜNG CÓ BỆNH THẬN MẠN
}

\author{
Đào Thị Thúy*, Nguyễn Thị Băng Sương*, \\ Vũ Quang Huy*, Đoàn Thanh Hải*, Hà Mạnh Tuấn*.
}

\section{TÓM TẮT}

Mục tiêu: 1) Xác định nồng độ Fructosamin huyết thanh ở bệnh nhân đái tháo đường có bệnh thận mạn tính. 2) Xác đinh mối liên quan giữa nồng đô Fructosamin huyết thanh với đường huyết lúc đói và nồng độ $\mathrm{HbA1C}$ ở bệnh nhân đái tháo đường có bệnh thận mạn tính. Phương pháp nghiên cứu: Nghiên cứu bênh chứng. 136 bểnh nhân được đưa vào nghiên cứu chia thành 3 nhóm: nhóm bệnh nhân đái tháo đường có mức loc cầu thận (MLCT) $<60 \mathrm{ml} / \mathrm{p}$ (nhóm đái tháo đường bệnh thận mạn-ĐTĐBTM), nhóm bệnh nhân đái tháo đường có $\mathrm{MLCT} \geq 60 \mathrm{ml} / \mathrm{p}$ (nhóm đái tháo đường không bệnh thận mạn- ĐTĐKBTM) và nhóm người khỏe mạnh (NKM). Tất cả các bệnh nhân đều được định lượng Fructosamin huyết thanh, đường huyết lúc đói, HbA1C và các chỉ số sinh hóa có liên quan khác. Kết quả: Có 136 bệnh nhân được đưa vào nghiên cứu, trong đó có 50 bệnh nhân thuộc nhóm ĐTĐBTM, 56 bênh nhân ĐTĐKBTM và 30 bênh nhân thuộc NKM. Nồng độ Frucosamin huyết thanh trung bình ở nhóm ĐTĐBTM là $316.1 \pm 53.2 \mu \mathrm{mo} / \mathrm{l}$, cao hơn so với NKM là $60 \pm 27.4 \mu \mathrm{mo} / \mathrm{l}(\mathrm{p}<0.05)$; thấp hơn so với nhóm ĐTĐKBTM là $22.4 \pm 39.4 \mu \mathrm{mo} / \mathrm{l}$, tuy nhiên không có ý nghĩa thống kê $(p>0.05)$. Nồng độ Fructosamin huyết thanh không bị ảnh hưởng bởi Creatinin huyết thanh và $\mathrm{Hb}$. Nồng độ Fructosamin huyết thanh có mối tương quan thuận mức độ vửa với HbA1C ở nhóm ĐTĐBTM ( $r=0.388)$; và có mối tương quan thuận với nồng độ đường huyết lúc đói và

* Đai hoc Y Dước Thành Phố Hồ Chí Minh

Chịu trách nhiệm chính: Hà Mạnh Tuấn

Email: hamanhtuan@ump.edu.vn

Ngày nhận bài: 11.5.2021

Ngày phản biên khoa hoc: 28.6.2021

Ngày duyệt bài: 12.7.2021
HbA1C ở nhóm ĐTĐKBTM ( $r=0.487, r=0.466)$. Kết luận: (1) Nồng độ Fructosamin huyết thanh có mối tưởng quan thuận với nồng độ đường huyết lúc đói và HbA1C ở bệnh nhân đái tháo đường có bệnh thận mạn. (2) Nổng độ Fructosamin huyết thanh phản ánh được đường huyết lúc đói bệnh nhân đái tháo đường bệnh có bệnh thận mạn và không bị ảnh hưởng bởi các yếu tố suy thận, thiếu máu, nên là xét nghiệm có thể được dùng trong theo dõi và kiểm soát đường huyết ở bệnh nhân bệnh thận mạn.

Tư khóa: Đái tháo đường, bệnh thận mạn, Fructosamin, HbA1C.

\section{SUMMARY}

VALUE OF SERUM FRUCTOSAMIN IN REFLECTING FASTING GLUCOSE IN DIABETES MELLITUS WITH CHRONIC KIDNEY DISEASE

Objective: 1) Determine serum fructosamin concentration in diabetic patients with chronic kidney disease. 2) Determine the relationship between serum fructosamin concentration with fasting blood glucose and $\mathrm{HbA} 1 \mathrm{C}$ concentration in diabetic patients with chronic kidney disease. Methods: A case control study was conducted with 3 groups: a group of diabetic patients with glomerular filtration rate $<60 \mathrm{ml} / \mathrm{p}$ (diabetic group with chronic kidney disease), a group of diabetic patients with glomerular filtration rate $\geq 60 \mathrm{ml} / \mathrm{p}$ (diabetes without chronic kidney disease) and a group of healthy people. All patients have serum fructosamin, fasting blood glucose, $\mathrm{HbA1C}$ and other relevant biochemical parameteres measured. Results: There were 136 patients included into 3 groups: 50 diabetic patients with chronic kidney disease, 56 diabetic patients without chronic kidney disease and a healthy group of 30 people. (1) The mean concentration of Frucosamine in the diabetic group with chronic kidney disease was $316.1 \pm 53.2$ 
$\mu \mathrm{mo} / \mathrm{I}$, higher than in the healthy group $60 \pm 27.4$ $\mu \mathrm{mo} / \mathrm{l}(\mathrm{p}<0.05)$; lower than diabetes in the group without disease $22.4 \pm 39.4 \mu \mathrm{mo} / \mathrm{l}$, but there was no statistical significance $(p>0.05)$. (2) Fructosamin has a sufficient correlation with $\mathrm{HbA} 1 \mathrm{C}$ in diabetic patients with chronic kidney disease $(r=0.388)$; and has the same correlation with fasting blood glucose and HbA1C concentration in diabetic patients without chronic kidney disease $(r=0.487, \quad r=0.466)$. Conclusion: (1) Fructosamin concentration has a positive relationship with fasting blood glucose and $\mathrm{HbA1C}$ concentration in the group of diabetic patients. (2) Fructosamin concentration reflects fasting blood glucose, is not affected by chronic renal failure and anemia, so it can be used in monitoring and controlling blood glucose in diabetic patients with chronic kidney disease.

Keywords: Diabetes mellitus, Chronic kidney disease, Fructosamin, HbA1C.

\section{I. ĐẶT VẤN ĐỀ}

Đái tháo đường (ĐTĐ) là bệnh mạn tính, không truyền nhiễm, tỷ lệ mắc bệnh đảang gia tăng trên toàn thế giới và nó kéo theo sự phát triển của bệnh thận mạn tính (CKD) [1]. Tại Việt Nam, có khoảng 26.000 người bị suy thận mạn, bệnh thận giai đoạn cuối hay phải chạy thận nhân tạo và có khoảng 8.000 ca bệnh mắc mới. Đường huyết tăng cao kéo dài gầy nhiều biến chứng nguy hiểm, trong đó có làm suy giảm chức năng thận thậm chí làm tiến triển nhanh bệnh thận dấn đến bệnh thận giai đoạn cuối. Bệnh mang tính xã hội bởi chi phi điêu trị cao mà người bệnh có nguy cơ phải đối mặt với sự tàn phế thậm chí tử vong [2].

Để theo dõi và đánh giá hiệu quả việc kiểm soát đường huyết, hiện nay sử dụng chỉ số Glucose huyết thanh và HbA1C. Glucose máu phản ánh nồng độ đường máu tại thời điểm lấy máu xét nghiệm và có giá trị dao trong trong ngày khác nhau. HbA1C được xem là tiêu chuẩn vàng trong chẩn đoán, theo dõi và đánh giá đường huyết trung bình trên bệnh nhân đái tháo đường. Tuy nhiên, trường hợp bệnh nhân đái tháo đường cóbệnh thận mạn tính có thiếu máu và giảm mức lọc câu thận có ảnh hưởng đến chuyển hóa huyết sắc tố và sự lưu thông của các tế bào hồng câu già. Lúc này, nồng độ đường huyết thông qua xét nghiệm $\mathrm{HbA} 1 \mathrm{C}$ có thể không phản ánh đúng đường huyết của bệnh nhân [3]. Fructosamin là sản phẩm đường hóa của Albumin, phản ánh lượng đường trung bình 14-28 ngày tương đương với thời gian bán hủy của Albumin. Chính vì thế, Fructosamin có thể được xem là lựa chọn thay thế, kết hợp theo dõi, chẩn đoán trong những trường xét nghiệm HbA1C không phản ánh đúng giá trị đường huyết.
Nghiên cứu này khảo sát nông độ Fructosamin huyết thanh ở bệnh nhân đái tháo đường có bệnh thận mạn để đánh giá giá trị của Fructosaminh huyết thanh trong phản ánh đường huyết ở bệnh nhân có bệnh thận mạn thông qua việc 1) Xác định nông độ Fructosamin huyêt thanh ở bệnh nhân đái tháo đường có bệnh thận mạn tính; và 2) Xác định môi liên quan giữa nồng độ Fructosamin huyêt thanh với đường huyết lúc đói và nồng độ HbA1C ở bệnh nhân đái tháo đường có bệnh thận mạn tính.

\section{II. ĐỐI TƯỢNG VÀ PHƯƠNG PHÁP NGHIÊN CỨU}

Thiết kế nghiên cứu: Nghiên cứu bệnh chứng.

Dân số nghiên cứu và tiêu chuẩn chọn mẫu

Bệnh nhân đái tháo đường đến khám, điêuu trị và bệnh nhân đến khám sức khỏe tại khoa khám bệnh của cơ sở 2 thuộc Bệnh viện Đại học Y Dược Thành Phố Hồ Chí Minh từ tháng 10/2020 đến tháng 04/2021, thỏa các tiêu chí sau:

Tiêu chuẩn đưa vào: Bệnh nhân từ đủ 18 tuổi trở lên và đồng ý tham gia nghiên cứu.

a) Tiêu chuẩn đưa vào nhóm bệnh đái tháo đường có bệnh thận mạn (BTĐBTM): bệnh nhân đã được chẩn đoán và điêu trị bệnh đái tháo đường theo tiêu chuẩn của Hiệp hội Đái Tháo Đường Hoa Kỳ (ADA) và đã được chẩn đoán bệnh thận mạn với MLCT< 60ml/p trong khoảng từ 6 tháng trở lên.

b) Tiêu chuẩn đưa vào nhóm bệnh đái tháo đường không có bệnh thận mạn (BTĐKBTM): bệnh nhân đã được chẩn đoán và điều trị ĐTĐ theo tiêu chuẩn của Hiệp hội Đái Tháo Đường Hoa Kỳ (ADA) và có $M L C T \geq 60 \mathrm{ml} / \mathrm{p}$. Bệnh nhân có tuổi và giới tính tương đồng với nhóm bệnh đái tháo đường có bệnh thận mạn.

c) Tiêu chuẩn nhóm người khỏe mạnh (NKM): tiên sử khỏe mạnh, không phù, không tăng huyết áp, không rối loạn glucose máu, không tổn thương gan, thận.

Tiêu chuẩn loại trừ: bệnh nhân có bệnh về máu kèm theo (bệnh bất thường về Hemoglobin, đa u tủy xương, leukemia cấp, suy tủy xương, suy tim nặng, có thai, xơ gan, nghiện rượu,...); Bệnh nhân có hàm lượng Albumin máu dưới $3.5 \mathrm{~g} / \mathrm{dl}$ do các nguyên nhân khác nhau (xơ gan mất bù, viêm gan cấp, hội chứng thận hư, suy dinh dưỡng, bệnh lý ác tính,...); Bệnh nhân đang trong tình trạng nhiễm trùng cấp tính; Mẫu tán huyết.

Cỡ mẫu: Cõ̃ mẫu được tính theo công thức so sánh hai trung bình với hệ số đã biết

$$
\mathrm{n} 1 \geq \frac{\left(z_{1-\alpha / 2}+z_{1-\beta}\right)^{2}\left(\sigma_{1}^{2}+\sigma_{2}^{2} / r\right)}{\left(\mu_{1}-\mu_{2}\right)^{2}} \mathrm{n} 2=\mathrm{n} 1 \times \mathrm{r}
$$


(n1: nhóm bệnh nhân đái tháo đường có bệnh thận mạn, n2 : nhóm bệnh nhân đái tháo đường không có bệnh thận mạn).

Trong đó, chọn độ tin cậy $95 \%$ với hệ số a = 0.05 , và sai số cho phép chọn $\beta$ là 0.1 ; với nồng độ Fructosamin ở nhóm có bệnh thận mạn: 395,28 \pm 74,82 $\mu \mathrm{mol} / /$ [4], ở nghiên cứu của chúng tôi ước tính Fructosamin trung bình tăng $15 \%$; cõ mẫu tối thiểu là 34. Ngoài ra, chúng tôi chọn thêm 30 người khỏe mạnh để đánh giá nồng độ Fructosamin như thể nào trên người bình thường.

Phương pháp thu thâp số liệu. Tất cả bệnh nhân đến khám bệnh đái tháo đường và bệnh đái tháo đường/bệnh thận mạn, và các bệnh nhân đến khám sức khỏe tại khoa Khám bệnh - Bệnh viện Đại học Y Dược cơ sở 2 từ tháng 10/2020 đến tháng 04/2021. Bệnh nhân thỏa tiêu chuẩn chọn mẫu sẽ được mời tham gia nghiên cứu và tiến hành phỏng vấn. Thu thập kết quả xét nghiệm tại thời điểm bệnh nhân đến khám dựa trên phiếu thu thập số liệu. Vào ngày đến khám bệnh, bệnh nhân được lấy $3 \mathrm{ml}$ máu tĩnh mạch vào ống có chứa chất chống đông Heparin hoặc ống Serum, ly tâm 4000 vòng/phút trong 5 phút, tách lấy huyết thanh, huyết tương để định lượng: Glucose, Creatinin, Albumin và xét nghiêm đinh lượng Hemoglobulin và $\mathrm{HbA} 1 \mathrm{C}$ dùng chất chống đông EDTA.Tất cả các xét nghiệm được định lượng trong vòng 30 phút sau khi lấy máu. Định lượng nồng độ Fructosamin bằng phương pháp đo mật độ quang, phân tích bằng máy sinh hóa tự động AU480 tại Trung tâm Kiểm Chuẩn Chất lượng xét nghiệm Thành Phố Hồ Chí Minh.

Phân tích số liệu. Nhập liệu bằng phần mềm Microsoft Office Excel và phân tích, xử lý sô liệu bằng phần mềm Sata 14.0. Sử dụng phép toán thống kê trên dân số nghiên cứu bằng phương trình hồi quy tuyến tính; So sánh trung bình của 2 nhóm bằng $\mathrm{T}$ - test; Kiểm đinh ANOVA; Đường cong ROC được sử dụng để phân tích giá trị của xét nghiệm chẩn đoán.

Nghiên cứu được thông qua bởi Hội Đồng $Y$ Đức Đai họ $Y$ Dược Thành Phố Hồ Chí Minh theo quyêtt đinh số 640/HĐĐĐ-ĐHYD và chấp thuận của Bệnh viện Đại học Y Dược TP. Hồ Chí Minh cơ sở 2.

\section{KẾT QUẢ NGHIÊN CỨU}

Trong thời gian nghiên cứu từ tháng 10/2020 đến tháng 04/2021, chúng tôi thu thập được được 136 bệnh nhân đến khám tại khoa khám bênh - Bệnh viên Đại học Y Dược Thành Phố Hồ Chí Minh cơ sở 2 đủ tiêu chuẩn và đưa vào nghiên cứu; được chia thành 3 nhóm: nhóm ĐTÐBTM có 50 ca; nhóm ĐTĐKBTM có 56 ca và nhóm NKM có 30.

Bảng 1. Đặc điểm dân số tuổi và giới của các nhóm tham gia nghiên cứu

\begin{tabular}{|c|c|c|c|c|c|c|c|}
\hline \multicolumn{2}{|c|}{ 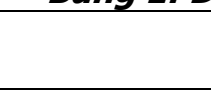 } & $\begin{array}{c}\text { ĐTÐBTM } \\
\mathbf{N}=50\end{array}$ & $\begin{array}{c}\text { ĐTÐKBTM } \\
N=56\end{array}$ & $\begin{array}{c}\text { NKM } \\
\mathbf{N}=\mathbf{3 0}\end{array}$ & $\mathrm{p} 1$ & p2 & p3 \\
\hline \multirow{2}{*}{ Giới } & Nam & $13(26.0)$ & $22(39.3)$ & $15(50.0)$ & \multirow{2}{*}{0.149} & \multirow{2}{*}{0.032} & \multirow{2}{*}{0.340} \\
\hline & Nữ & $37(74)$ & $34(60.7)$ & $15(50)$ & & & \\
\hline & |ối & $68.3 \pm 11.5$ & $60 \pm 11.6$ & $46.1 \pm 10.2$ & $<0.001$ & $<0.001$ & $<0.001$ \\
\hline
\end{tabular}

p1, Nhóm ĐTÐBTM so với ĐTÐKBTM; p2, Nhóm ĐTĐBTM so với NKM; p3, Nhóm TĐKBTM so với NKM.

Tuổi trung bình ở nhóm đái tháo đường bệnh thận mạn là $68.3 \pm 11.5$ tuổi, ở nhóm đái tháo đường không bênh thận mạn là $60 \pm 11.6$ tuổi và nhóm người khỏe mạnh là $46.1 \pm 10.2$ tuổi. Có sự khác biệt có ý nghĩa thống kê về tuổi trung bình ở cả ba nhóm $(p<0.001<0.05)$. Nữ giới chiếm đa số ở nhóm đái tháo đường bệnh thận mạn và không bệnh thận mạn, tuy nhiên ở nhóm khỏe mạnh tỉ lệ giới nam và nữ là $1: 1$.

Bảng 2: Giá trị của Fructosamin ở các nhóm tham gia nghiên cứu

\begin{tabular}{|c|c|c|c|c|c|c|}
\hline & \multicolumn{2}{|c|}{ Đái tháo đường } & \multirow{2}{*}{$\begin{array}{l}\text { NKM } \\
n=30\end{array}$} & \multirow[b]{2}{*}{ p1 } & \multirow{2}{*}{ p2 } & \multirow{2}{*}{ p3 } \\
\hline & BTM $n=50$ & KBTM $n=56$ & & & & \\
\hline Fructosamin & $316.1 \pm 53.2$ & $338.5 \pm 92.6$ & $256.0 \pm 25.8$ & 0.096 & $<0.001$ & $<0.001$ \\
\hline
\end{tabular}

p1, Nhóm ĐTÐBTM so với ĐTÐKBTM; p2, Nhóm ĐTĐBTM so với NKM; p3, Nhóm TĐKBTM so với NK.

Nồng độ Fructosamin trung bình ở nhóm đái tháo đường bệnh thận mạn là $316.1 \pm 53.2 \mu \mathrm{mo} / \mathrm{l}$ cao hơn so với nhóm người khỏe mạnh là $60 \pm$ $27.4 \mu \mathrm{mo} / \mathrm{l} \quad(\mathrm{p}=0.001<0.05)$, thấp hơn so với nhóm đái tháo đường không bệnh thận là $22.4 \pm$
39.4 mo/l, tuy nhiên không có ý nghĩa thống kê ( $p>0.05)$.

Bảng 3. Các yếu tố ảnh hưởng đến nồng độ Fructosamin huyêt thanh

\begin{tabular}{|c|c|c|}
\hline \multirow{2}{*}{ Fructosamin } & \multicolumn{2}{|c|}{ Toàn mâu $\mathbf{( N = 1 3 3 )}$} \\
\cline { 2 - 3 } & $\mathbf{r}$ & $\mathbf{p}$ \\
\hline MLCT & -0.114 & 0.186 \\
\hline Creatinin & 0.021 & 0.805 \\
\hline
\end{tabular}




\begin{tabular}{|c|c|c|}
\hline $\mathrm{Hb}$ & -0.04 & 0.642 \\
\hline (MLCT: mức lọc câu thận, $\mathrm{Hb}$ : Lượng \\
Hemoglobulin trung bình hồng cầu).
\end{tabular}

Fructosamin có mối tương quan nghịch với

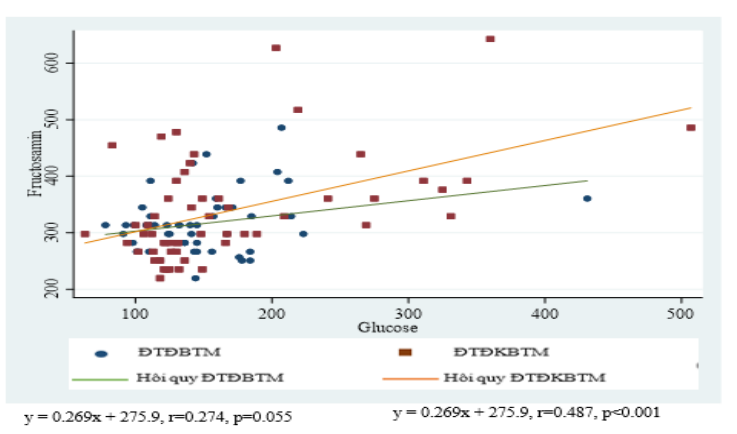

Biểu đồ 1. Mồi liên quan giữa

Fructosamin và đường huyết lúc đói ở bệnh nhân đái tháo đường.

Fructosamin huyết thanh có mối tương quan thuận với nồng độ đường huyết lúc đói ở nhóm đái tháo đường bệnh thận mạn, tuy nhiên không có ý nghĩa thống kê $(r=0.274, p>0.05)$. Fructosamin huyết thanh có mối tương quan thuận với nồng độ đường huyết lúc đói ở nhóm đái tháo đường không bệnh thận mạn $(r=0.487$, $\mathrm{p}<0.05$ ). Fructosamin có mối tương quan thuận mức độ trung bình với $\mathrm{HbA} 1 \mathrm{C}$ ở nhóm đái tháo đường bệnh thận mạn và không bệnh thận mạn $(r=0.388, r=0.466, p<0.05)$

\section{BÀN LUÂN}

Nghiên cứu được tiến hành trên 136 đối tương, chia thành 3 nhóm: 50 bênh nhân đái tháo đường bệnh thận mạn, 56 bệnh nhân đái tháo đường không bệnh thận mạn, và 30 người khỏe mạnh với mục tiêu xác định nồng độ Fructosamin và mối liên quan của nồng đổ Fructosamin với nồng độ đường huyết lúc đói, HbA1C ở bệnh nhân đái tháo đường bệnh thận mạn; Giá trị của Fructosamin có bị ảnh hưởng khi bệnh nhẩn có bênh thân mạn hay không.

Nghiên cứu này ghi nhận nhóm đái tháo đường bệnh thận mạn có tuổi trung bình cao nhất là 68.3 * 11.5 tuổi, cao hơn tuổi trung bình ở nhóm đái tháo đường không bệnh thận $60 \pm$ 11.6 tuổi và nhóm người khỏe mạnh $46.1 \pm 10.2$ tuổi, sự khác biệt này có ý nghĩa thống kê $(p<0.001<0.05)$. Đối tượng tham gia nghiên cứu đa số là những bênh nhân lớn hơn 60 tuổi. Kết quả nghiên cứu cho thấy tỉ nữ giới chiếm tỉ lệ cao hơn nam giới: ở nhóm đái tháo đường bệnh thận mạn có tî lệ giới nữ là $74 \%$, nhóm đái tháo chỉ số MLCT, Hb; có mối tương quan thuận với Creatinin, tuy nhiên đều không có ý nghĩa thống kê $(p>0.05)$. Có thể nói Fructosamin không bị ảnh hưởng bởi các yễu tố này.

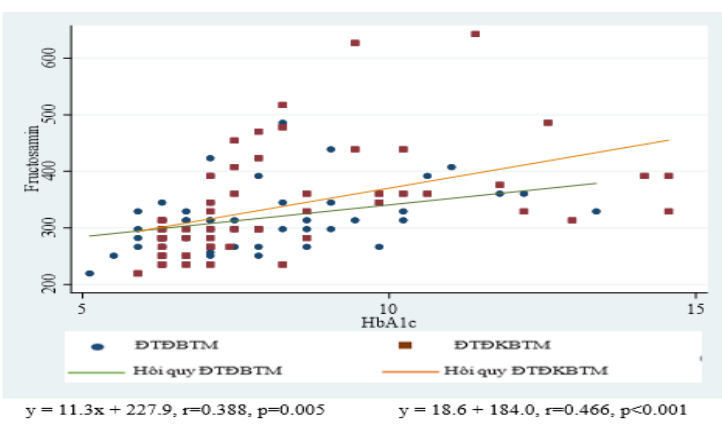

Biêu đô 2. Môi liên quan giữa Fructosamin với HbA1C ö̉ bệnh nhân đái tháo đường

đường không bệnh thận tỉ lệ giới nữ là 60,7\%.

Fructosamin phản ánh đường máu trung bình 2-3 tuần; giá trị của Fructosamin bình thường

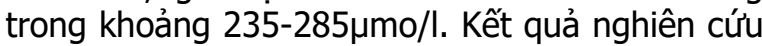
của chúng tôi cho thấy, nông độ Fructosamin ở nhóm đái tháo đường bệnh thận mạn là $316.1 \pm$ $53.2 \mu \mathrm{mo} / \mathrm{l}$ thấp hơn nhóm đái tháo đường không bênh thận $338.5 \pm 92.6 \mu \mathrm{mo} / \mathrm{l}$, sự khác biệt này không có ý nghĩa thống kê ( $p>0.05)$; nồng độ Fructosamin của hai nhóm đái tháo đường có bệnh thận và không bệnh thận đều cao hơn ngưỡng bình thường $>285 \mu \mathrm{mo} / \mathrm{l}$. Nồng độ Fructosamin ở nhóm người khỏe manh là 256.0 $\pm 25.8 \mu \mathrm{mo} / \mathrm{l}$ đều dưới ngưỡng bình thường < $285 \mu \mathrm{mo} / \mathrm{l}$; nồng độ Fructosamin ở nhóm đái tháo đường bệnh thận mạn và không bệnh thận mạn đều cao hơn nhóm người khỏe mạnh $(p=0.001$ $<0.05)$; Điều này là do bệnh nhân đái tháo đường có nồng độ đường huyết tăng cao, làm đường huyết gắn kết với Albumin tăng và làm tăng nồng độ Fructosamin. Kết quả này phù hợp với nghiên cứu của các tác giả [1],[6]. Nghiên cứu của chúng tôi khác biệt so với nghiên cứu của tác giả $\mathrm{Km}$ Neelofar: nồng đô Fructosamin ở nhóm đái tháo đường bệnh thận mạn là 395.28 $\pm 74.82 \mu \mathrm{mo} / \mathrm{l}$ cao hơn so với nhóm không bệnh thận mạn là $315.42 \pm 35.3 \mu \mathrm{mo} / \mathrm{l}$; sự khác biêt này có thể do các bênh nhân của nghiên cứu chúng tôi tuân thủ trong điều trị cao hơn, ngoài ra còn có thể do sự khác biệt về quần thể chọn mẫu. Kết quả nghiên cứu cho thây Fructosamin có mối liên quan chặt chẽ với các chỉ số đường huyết của bệnh nhân, nên nồng độ Fructosamin phản ánh được nồng độ đường huyết lúc đói. 
Kết quả nghiên cứu cũng cho thấy, Fructosamin không có mối liên quan với các chỉ số mức lọc cầu thận, Creatinin, Hemoglobin. Phát hiện này cho thấy giá trị của Fructosamin không bị ảnh hưởng bởi mức độ suy thận và thiếu máu.

Khi khảo sát về mối liên quan của nồng độ Fructosamin với đường huyết lúc đói và $\mathrm{HbA1C}$, nghiên cứu này ghi nhận như sau. Ở nhóm bệnh đái tháo đường không bệnh thận mạn, nồng đô Fructosamin có mối tương quan thuận mức độ trung bình với đường huyết lúc đói và $\mathrm{HbA} 1 \mathrm{C}$ $(r=0.487, r=0.466), p<0.001<0.05$; nồng đô đường huyết lúc đói càng cao thì nồng độ Fructosamin và $\mathrm{HbA} 1 \mathrm{C}$ càng cao; nghiên cứu của chúng tôi tương đồng với nghiên cứu của các tác giả trong nước và ngoài nước [3], [7], [8].

Trong nhóm đái tháo đường bênh thận mạn, ghi nhận mối tương quan thuận của Fructosamin với HbA1C, $\mathrm{p}=0.005<0.05$; có mối tương quan thuận với nồng độ đường huyết lúc đói, tuy nhiển chưa có ý nghĩa thống kê ( $p>0.05)$ điều này có thể do cỡ mẫu nghiên cứu của chúng tôi chưa đủ lớn. Tuy nhiên, khi nhìn chung ở toàn mẫu thì có mối tương quan thuận mức độ trung bình giữa Fructosamin với đường huyết lúc đói và HbA1C. Nghiên cứu của chúng tôi có sự tương đồng với nghiên cứu của các tác giả [3], [4].

Kết quả nghiên cứu ghi nhận, Fructosamin với HbA1C ở hai nhóm đái tháo đường bệnh thận mạn và không bệnh thận mạn đều có mối tương quan chặt như nhau ( $r=0.388, r=0.466)$. Mối tương quan của nồng độ Fructosamin với đường huyết lúc đói ở nhóm không bệnh thân chặt chẽ hơn so với nhóm đái tháo đường bệnh thận mạn $(r=0.487, r=0.274)$. Mối liên quan giữa Fructosamin với HbA1C ở hai nhóm đêu cao hơn mối tương quan giữa Fructosamin với đường huyết lúc đói. Lí giải cho sự khác biệt này, có thể do đường huyết lúc đói đánh giá nồng độ đường huyết tại thời điểm xét nghiệm, giá trị này dao động khác nhau giữa các thời điểm trong ngày và giữa các ngày; Fructosamin phản ánh đường huyết trung bình từ 2-3 tuần; $\mathrm{HbA1C}$ phản ánh đường huyết trung bình trong 2-3 tháng. Do đó, mối tương quan của Fructosamin với đường huyết lúc đói không chặt chẽ như với HbA1C. Nhìn chung, kết quả nghiên cứu của chúng tôi cho thây Fructosamin phản ánh được đường huyết lúc đói của bệnh nhân đái tháo đường bệnh thận mạn.

Fructosamin là xét nghiệm đơn giản có thể định lượng trên huyết tương hoặc huyết thanh, xét nghiệm dễ thực hiện, không phụ thuộc vào thời gian lấy máu, giá thành thẩp hớn xét nghiệm $\mathrm{HbA1C}$, thời gian phản ánh đường huyết trung bình 2-3 tuần giúp phát hiện những bệnh nhân có sự thay đổi đường huyết trong thời gian ngắn, thêm vào đó Fructosamin không bị ảnh hưởng bởi bệnh thận, thiếu máu, do đó Fructosamin có thể xem là môt xét nghiêm tiềm năng để kết hợp với HbA1C trong theo dõi đường huyết ở bệnh nhân đái tháo đường có chức năng thận suy giảm, có thiếu máu.

\section{KẾT LUÂNN}

Nồng độ Fructosamin huyết thanh phản ánh đúng đường huyết lúc đói của bệnh nhân tiểu đường có bệnh thận mạn và không bị ảnh hưởng bởi mức lọc cầu thận và tình trạng thiếu máu. Xét nghiệm định lượng Fructosamin dễ dàng thực hiện, cho kết quả nhanh và giá thành chấp nhận được nên khuyến nghị là sử dụng để đánh giá và theo dõi đáp ứng điều trị ở bệnh nhân tiểu đường nhất là bệnh nhân có bệnh thận mạn.

\section{TÀI LIÊU THAM KHẢO}

\section{Vos F E, Schollum J B, Coulter C V, Manning P} J, et al, (2012), "Assessment of markers of glycaemic control in diabetic patients with chronic kidney disease using continuous glucose monitoring", Nephrology (Carlton), 17 (2), pp. 182-188.

2. Ta Văn Bình, và công sứ, (2017), "Sống khỏe với đái tháo đường", Tạp chí đái tháo đường, tr. 1- 26.

3. Cindy George, Tandi E. Matsha, Marizna Korf, Annalise E. Zemlin, et al, (2020), "The agreement between fasting glucose and markers of chronic glycaemic exposure in individuals with and without chronic kidney disease: a crosssectional study", BMC Nephrol, 21 (1), pp. 32.

4. Neelofar K, Ahmad J, (2019), "A comparative analysis of fructosamine with other risk factors for kidney dysfunction in diabetic patients with or without chronic kidney disease", Diabetes \& Metabolic Syndrome: Clinical Research \& Reviews, 13 (1), pp. 240-244.

5. Shohat $\mathbf{N}$, Tarabichi M, Tan $\mathbf{T}$ L, Goswami K, et al, (2019), "2019 John Insall Award: Fructosamine is a better glycaemic marker compared with glycated haemoglobin (HbA1C) in predicting adverse outcomes following total knee arthroplasty: a prospective multicentre study", Bone Joint J, 101-b (7_Supple_C).

6. Chen H S, Wu T E, Lin H D, Jap T S, et al, (2010), "Hemoglobin $A(1 c)$ and fructosamine for assessing glycemic control in diabetic patients with CKD stages 3 and 4", Am J Kidney Dis, 55 (5), pp. 867-874.

7. Lê Thị HươngThu (2016), "Nồng đô fructosamin huyết thanh trong đánh giá mức đồ kiểm soát đường máu ở bệnh nhân đái tháo đường typ 2 điều trị ngoại trú tại bệnh viện trung ương thái nguyên", tr. 31-41.

8. Nguyễn Thu Giang, Lê Thị Hương Lan, (2018), "Nồng độ fructosamin huyết tương và mối liên quan với một số chỉ số sinh hóa máu ở bệnh nhân đái tháo đường type 2 điều trị tại bệnh viện trung ương thái nguyên", tr. 35-55. 